\title{
Genetic divergence among soybean cultivars in irrigated lowland in the State of Tocantins
}

\author{
Divergência genética entre cultivares de soja em várzea irrigada no Estado do Tocantins
}

\author{
Joênes Mucci Peluzio' Luiz Paulo Miranda Pires ${ }^{\text {II }}$ Leandro Lopes Cancellier ${ }^{\text {III }}$ \\ Flávio Sérgio Afférri ${ }^{\mathrm{I}}$ Gustavo André Colombo ${ }^{\mathrm{I}}$ Thadeu Teixeira Júnior $^{\mathrm{I}}$ \\ Glauber Ronery dos Santos Ribeiro ${ }^{\mathrm{I}}$
}

\begin{abstract}
In order to evaluate the genetic divergence among soybean cultivars, an assay was carried out at Formoso do Araguaia, TO, Brazil, in off-season of 2007, in irrigated lowland conditions. The experimental design were randomized blocks with 12 treatments and three replications. Genetic divergence was evaluated by multivariate procedures: Mahalanobis distance, Tocher clustering method's and nearest neighbor method. It was observed the formation of two distinct groups by the dendrogram of genetic dissimilarity, which were identical to those groups formed by Tocher's method. The Tocher optimization method and the nearest neighbor agreed among themselves. The traits number of days to maturity, plant height and weight of 100 seed were the ones that most contributed for genetic dissimilarity. The presence of genetic variability allowed the identification of dissimilar cultivars with high average for the evaluated traits. The hybridations 'DOKO' $x$ 'CONQUEST' and 'DOKO' $x$ 'FT-2000' are promising to obtain segregating populations with high variability
\end{abstract}

Key words: Glycine max, genetic variability, hybrid combination.

\section{RESUMO}

Com objetivo de avaliar a divergência genética entre cultivares de soja, foi realizado o ensaio, no município de Formoso do Araguaia, na entressafra de 2007, em condições de várzea irrigada. O delineamento utilizado foi de blocos casualizados, com 12 tratamentos e três repetições. A divergência genética foi avaliada por procedimentos multivariados: distância generalizada de Mahalanobis, método de agrupamento de Tocher e método vizinho mais próximo. Foi observada a formação de dois grupos distintos pelo dendrograma de dissimilaridade genética, que foi idêntico aos grupos formados pelo método de Tocher. As características número de dias para maturação, altura de plantas e peso de 100 sementes foram as que mais contribuíram na dissimilaridade genética. A presença de variabilidade genética permitiu a identificação de cultivares dissimilares e com média elevada nas características estudadas. As hibridações 'DOKO' $x$ 'CONQUISTA' $e$ 'DOKO' $x$ 'FT-2000' são promissoras para obtenção de populações segregantes com alta variabilidade.

Palavras-chave: Glycine max, variabilidade genética, combinação híbrida.

\section{INTRODUCTION}

Soybean is considered one of the most important leguminous. It is a species of great economic interest in function of the elevated level of protein (40\%), oil (20\%) and yield (SEDIYAMA et al., 2005). The State of Tocantins has potential of about 1 million hectares of lowland, being cultivated currently about 50000 hectares. However, in spite of the limited availability of cultivars adapted to cultivation in this condition, few studies at this time have being conducted to quantify the phenotypic divergence for breeding purposes.

In soybean breeding, when is wanted the obtainment of segregating populations, several difficulties are found, one of them is the choice of parents

IUniversidade Federal do Tocantins (UFT), Campus de Gurupi, Gurupi, TO, Brasil.

IIUniversidade Federal de Lavras (UFLA), Departamento de Biologia (DBI), Lavras, MG, Brasil.

IIIULA, Departamento de Agricultura (DAG), CP 3037, 37200-000, Lavras, MG, Brasil. E-mail: leandrocancellier@gmail.com. Autor para correspondência. 
to be crossed. The soybean's breeding programs have been focusing on development of more productive cultivars. For this, the breeder has been using the germplasm, adapted and wild germplasm in order to find the genetic variability. These new materials and derived inbred lines need to be characterized concerning physiological matters, which require a long period (SEDIYAMAet al., 2005).

In the choice of parents, it's crucial the knowledge of crops problems in the region, in some cases, it could exist many potential parents. To resolve this problem, breeders are usually based on important information to take a decision, such as the agronomic superiority, genetic divergence, the combination and the parents per se behavior.

In the genetic diversity's studies of one population or individuals, agronomic, morphological and molecular characters are used, which, in turn, are submitted to multivariate biometric techniques, allowing to unify multiple information from a set of characters that results in greater opportunities in the choice of divergent parents in breeding programs(CRUZ \& REGAZZI, 2004; CEOLIN et al., 2007; ASMUS, 2008).

Among the multivariate statistical techniques, there is the Tocher's optimization and the hierarchical nearest neighbor methods (CRUZ \& REGAZZI, 2004). A lot of studies of plant breeding have been using multivariate techniques in the study of genetic divergence (ARAVIND, 2006; MAIAet al., 2006; IQBAL et al., 2010; MIKEL et al., 2010; ALMEIDA et al., 2011; LIU, et al., 2011; MALIK et al., 2011; PATIL et al., 2011).

The objectives of this study involving soybean genotypes cultivated in irrigated lowland in State of Tocantins are: quantify the genetic variability of cultivars; promote the genotype clustering according to genetic dissimilarity; indicate the relative contribution of characteristics in the genetic dissimilarity and identify superior hybrid combinations in the progeny selection.

\section{MATERIAL AND METHODS}

The experiment was carried out in lowland irrigated condition in off-season of 2007 at Formoso do Araguaia-TO, Brazil, in Gley Little-Humic soil at an altitude of $170 \mathrm{~m}$, under conventional management system. The result of soil chemical analysis used in the experiment, sampled at 0-20 cm depth was: 0.0 for $\mathrm{Al}\left(\mathrm{mmol}_{\mathrm{C}} \mathrm{dm}^{-3}\right) ; 8.1$ and 3.6 for Ca and $\mathrm{Mg}\left(\mathrm{mmol}_{\mathrm{c}} \mathrm{dm}^{-3}\right)$ respectively; 0.46 and 23.7 for $\mathrm{K}$ and $\mathrm{P}\left(\mathrm{mg} \mathrm{dm}^{-3}\right)$ respectively, and 5.6 $\mathrm{pH}\left(\mathrm{H}_{2} \mathrm{O}\right)$.
The experimental design were randomized blocks with twelve treatments corresponding to cultivars (FT-104; FT-106; FT-107; M-SOY 108; M-SOY 109; EMGOPA 314; FT 2000; FT STRELA; CONQUISTA; CRISTALINA; DOKO and DM NOBRE) in three replications, with sowing date at 06/21/2007, traditionally cultivated in the off-season.

The experimental plot was composed by four lines of five meters long, with spacing of 0.40 meters interlines. Disking, plowing and grooving operations were carried out. At the sowing time it was performed the seeds treatment, followed by seed inoculation with $\boldsymbol{B}$. japonicum strains. The sowing density was carried out aiming to obtain 10 to 16 plants per linear meter, according to the cultivar recommendation. The crop management was carried out as it was necessary. The plants in each plot were harvested at $\mathrm{R}_{8}$. The plants were threshed and seeds were then weighed, after drying and cleaning, for grain yield determination.

Based on each plot area, it was obtained the following agronomic characteristics: number of days to flowering, number of days to maturity, plant height, height of first pod insertion; number of seeds per pod, number of pods per plant, weight of 100 seeds and grain yield.

The data were subjected to analysis of variance to assess the genetic variability. Next, it was carried out the analysis of variance of characteristics and then the average groups were compared by Scott-Knott criterion $(\mathrm{P} \leq 0.05)$. The dissimilarity measures were determined according to multivariate analysis model, which allowed to obtain the dissimilarity matrix, the residual covariance matrix and the average of cultivars.

Subsequently, the Tocher clustering methods (RAO, 1952) and the nearest neighbor were applied (REGAZZI \& CRUZ, 2004), using the Mahalanobis generalized distance $\left(\mathrm{D}^{2}\right)$ as dissimilarity measure. It was also used the SINGH (1981) criterion to quantify the relative contribution of these traits to genetic divergence.

\section{RESULTS AND DISCUSSION}

The results demonstrated the existence of significant differences among the means of cultivars for all characteristics, by F test $(\mathrm{P} \leq 0.05)$ (Table 1$)$, indicating that there are differences among cultivars and that differences may be used in breeding program with crosses among these cultivars and consequently the possibility of obtaining genetic gain for traits in evaluation. 
Table 1 - Analysis of variance of eight characteristics in twelve soybean cultivars at Formoso do Araguaia, TO, Brazil, off-season, 2007.

\begin{tabular}{|c|c|c|c|c|c|c|c|c|c|}
\hline \multirow{2}{*}{ SV } & \multirow{2}{*}{$\mathrm{DF}$} & \multirow{2}{*}{ NDF } & \multirow[b]{2}{*}{ NDM } & \multirow[b]{2}{*}{$\mathrm{PH}$} & \multirow[b]{2}{*}{ FPI } & \multirow{2}{*}{$\begin{array}{l}\text { Square } \\
\text { NSP }\end{array}$} & \multirow[b]{2}{*}{ NPP } & \multirow[b]{2}{*}{ W100S } & \multirow[b]{2}{*}{ GY } \\
\hline & & & & & & & & & \\
\hline Block & 2 & 0.78 & 4.69 & 26.8 & 8.33 & 0.004 & 1.19 & 0.34 & 2760.6 \\
\hline Cultivars & 11 & $11.9^{*}$ & $91.3^{*}$ & $182.7^{*}$ & $14.2^{*}$ & $0.03^{*}$ & $156.2^{*}$ & $18.4^{*}$ & 64489* \\
\hline Error & 22 & 0.96 & 1.69 & 10.2 & 3.64 & 0.01 & 9.67 & 0.79 & 4794.3 \\
\hline Means & - & 38.69 & 93.72 & 70.14 & 17.83 & 2.13 & 33.40 & 13.08 & 1053.0 \\
\hline CV (\%) & - & 2.53 & 1.39 & 4.57 & 10.69 & 5.67 & 9.31 & 6.80 & 6.58 \\
\hline
\end{tabular}

* Significant at $5 \%$ of significance by $\mathrm{F}$ test. Number of days to flowering (NDF), number of days to maturity (NDM), plant height (PH), height of first pod insertion (FPI); number of seeds per pod (NSP), number of pods per plant (NPP), weight of 100 seeds (W100S) and grain yield (GY).

The greatest heights of first pod insertion occurred in cultivars group 'CONQUISTA', 'FT-2000', 'EMGOPA-314', 'FT-106', 'FT-107', 'MSOY-108' and DOKO, which are different from the other group of cultivars. Usually the aim is to seek for cultivars with lowest height of first pod insertion (10 to $15 \mathrm{~cm})$ and higher plant height (60 to $80 \mathrm{~cm}$ ), since there is a trend of higher plants with lower height of first pod insertion which have larger pods number (BARROS et al., 2003). However, the selection of high plants with low height of first pod insertion could result in losses in mechanical harvesting.

The number of days to flowering and maturation, due to the crop thermo-photoperiodic sensitivity, are important characteristics in the cultivar choice, since, according to the climatic conditions, it becomes possible the stagger of sowing and harvesting, to reduce the risk of matching prolonged periods of water stress with the most critical stages of plant development (flowering and grain filling) and hydric excess close to the harvest. The cultivar 'DOKO' had the longest life cycle, differentiating statistically of the other cultivars, followed by cultivars group 'DM-NOBRE', 'FT-STRELA', 'CRISTALINA' and 'FT-104' which don't showed differences among themselves. The cultivar 'EMGOPA314' had the shortest life cycle, with an average of 84 days to flowering.

The highest number of pods per plant was obtained by 'FT-STRELA', differing itself from the other cultivar groups, followed by the cultivars 'CRISTALINA', 'FT-107' and 'DM-NOBRE'. The cultivar which showed the fewest pods per plant was 'MSOY-108', however, the number of pod per plants ranged from 23.7 to 50.7. BOARD et al. (1997), found that number of pods per plant was the characteristic that most contributes to the grain yield in leguminous, since it shows the highest correlations with grain production and pods with 1, 2 and 3 grains may influence the size of the seeds that will be produced and consequently grain yield.

The cultivar 'DOKO' showed greatest weight of 100 seeds, being superior to the other cultivar groups. The weight of 100 seeds is an important characteristic in the cultivar choice to be sown, since the acquisition of seeds of lower weight will result in a lower cost of production by area, compared to the larger volume of seed per unit sold and also in greater germination speed and emergence process.

The grain yield allowed to split cultivars into four groups. The cultivars 'FT-200', 'CONQUISTA' and 'DOKO' showed the highest grain yield, followed by cultivar groups that had grains yield below $1100.5 \mathrm{~kg} \mathrm{ha}^{-1}$. The group with the worst grain yield was composed of two cultivars: ‘EMGOPA-314' and 'MSOY-109'(Table 2).

The cluster analysis by Tocher method separated 12 cultivars into two groups (Table 3). In group I it was clustered eleven cultivars genetically similar (91.6\% of the cultivars total), indicating that the possible crosses of these cultivars among themselves decreases the possibility of obtaining superior genotypes. The cultivar 'DOKO' is isolated in group II, confirming the relative high value of their distances in the pairs that it participated.

The formation of these groups is of fundamental importance for choosing the parents, because new hybrids combinations to be established must be based on the magnitude of their dissimilarities and in the per se potential of the parents. The cultivars which were grouped into more distant groups give an indicative to be dissimilar, thus, they may be considered as promising in artificial crosses. However, apart from dissimilar, it is necessary that parents associate high grain 
Table 2 - Means of eight characteristics in twelve soybean cultivars at Formoso do Araguaia, TO, Brazil, off-season, 2007.

\begin{tabular}{|c|c|c|c|c|c|c|c|c|c|c|c|c|c|c|c|c|}
\hline \multirow{2}{*}{$\begin{array}{l}\text { Cultivars } \\
\text { 'FT-104' }\end{array}$} & \multicolumn{2}{|c|}{---NDF--- } & \multicolumn{2}{|c|}{---NDM--- } & \multicolumn{2}{|c|}{------PH------ } & \multicolumn{2}{|c|}{-----FPI----- } & \multicolumn{2}{|c|}{-----NSP----- } & \multicolumn{2}{|c|}{-----NPP----- } & \multicolumn{2}{|c|}{---W100S--- } & \multicolumn{2}{|c|}{-------GY ------ } \\
\hline & 36 & C & 96 & $\mathrm{~b}$ & 57.3 & $\mathrm{~d}$ & 13.7 & $\mathrm{~b}$ & 2.11 & $\mathrm{a}$ & 31.1 & c & 11.5 & C & 969.4 & c \\
\hline 'FT-106' & 40 & $\mathrm{a}$ & 92 & $\mathrm{~d}$ & 73.3 & $\mathrm{~b}$ & 18.7 & $\mathrm{a}$ & 2.25 & $\mathrm{a}$ & 28.8 & c & 11.6 & C & 1050.9 & $\mathrm{~b}$ \\
\hline 'FT-107' & 38 & $\mathrm{~b}$ & 94 & c & 73.0 & $\mathrm{~b}$ & 18.3 & $\mathrm{a}$ & 2.24 & $\mathrm{a}$ & 37.9 & $\mathrm{~b}$ & 13.0 & $\mathrm{~b}$ & 989.3 & c \\
\hline 'MSOY-108' & 39 & $\mathrm{~b}$ & 95 & $\mathrm{c}$ & 74.3 & $\mathrm{~b}$ & 18.3 & $\mathrm{a}$ & 1.98 & $\mathrm{a}$ & 23.7 & c & 14.2 & $\mathrm{~b}$ & 1100.5 & $\mathrm{~b}$ \\
\hline 'MSOY-109’ & 36 & $\mathrm{C}$ & 89 & e & 66.0 & C & 16.0 & $\mathrm{~b}$ & 2.18 & $\mathrm{a}$ & 31.5 & c & 11.9 & c & 750.9 & $\mathrm{~d}$ \\
\hline 'EMGOPA-314’ & 37 & $\mathrm{~b}$ & 84 & $\mathrm{f}$ & 72.7 & $\mathrm{~b}$ & 20.0 & $\mathrm{a}$ & 2.07 & $\mathrm{a}$ & 27.8 & c & 11.3 & c & 856.9 & $\mathrm{~d}$ \\
\hline 'FT-2000’ & 41 & $\mathrm{a}$ & 90 & e & 62.7 & $\mathrm{~d}$ & 20.3 & $\mathrm{a}$ & 2.10 & $\mathrm{a}$ & 30.9 & c & 13.3 & $\mathrm{~b}$ & 1239.3 & $\mathrm{a}$ \\
\hline 'CONQUISTA’ & 41 & $\mathrm{a}$ & 89 & e & 61.0 & $\mathrm{~d}$ & 21.0 & $\mathrm{a}$ & 2.21 & $\mathrm{a}$ & 28.9 & c & 13.3 & $\mathrm{~b}$ & 1230.1 & $\mathrm{a}$ \\
\hline 'CRISTALINA' & 40 & $\mathrm{a}$ & 96 & $\mathrm{~b}$ & 77.3 & $\mathrm{~b}$ & 15.0 & $\mathrm{~b}$ & 2.23 & $\mathrm{a}$ & 41.4 & $\mathrm{~b}$ & 12.7 & $\mathrm{~b}$ & 1094.4 & $\mathrm{~b}$ \\
\hline 'DOKO’' & 42 & $\mathrm{a}$ & 106 & $\mathrm{a}$ & 71.7 & $\mathrm{~b}$ & 18.3 & $\mathrm{a}$ & 1.93 & $\mathrm{a}$ & 31.7 & c & 20.4 & $\mathrm{a}$ & 1210.6 & $\mathrm{a}$ \\
\hline 'FT-ESTRELA' & 38 & $\mathrm{~b}$ & 97 & $\mathrm{~b}$ & 85.7 & $\mathrm{a}$ & 17.0 & $\mathrm{~b}$ & 2.18 & $\mathrm{a}$ & 50.7 & $\mathrm{a}$ & 11.3 & c & 1079.6 & $\mathrm{~b}$ \\
\hline 'DM NOBRE' & 38 & $\mathrm{a}$ & 97 & $\mathrm{~b}$ & 66.7 & c & 17.3 & $\mathrm{~b}$ & 2.03 & $\mathrm{a}$ & 36.2 & $\mathrm{~b}$ & 12.4 & c & 1063.9 & $\mathrm{~b}$ \\
\hline Mean & 38 & & 94 & & 70.1 & & 17.8 & & 2.13 & & 33.4 & & 13.1 & & 1052.9 & \\
\hline
\end{tabular}

* Mean groups followed by same letter in column do not differ among themselves by Scott-Knott criterion (P=0.05). Number of days to flowering (NDF), number of days to maturity (NDM), plant height (PH), height of first pod insertion (FPI); number of seeds per pod (NSP), number of pods per plant (NPP), weight of 100 seeds (W100S) and grain yield (GY).

yield average and variability in the characteristics that are being improved. Thus the distance of cultivar 'DOKO' in relation to those others from group I suggest that this may provide high heterotic effect after the hybridizations.

CRUZ \& REGAZZI (2004) suggest that there wasn't involvement of individuals with same pattern of dissimilarity at the crossings, not restricting the genetic variability, avoiding negative effects on earnings obtained by selection. As reported by ABREU et al. (1999) and CARPENTIERI-PÍPOLO et al. (2000), the best hybrid combinations to be tested in breeding program, should involve divergent parents with high average performance. According to CRUZ \& REGAZZI (2004), the establishment of groups with genotypes with homogeneity within and heterogeneity among groups is

Table 3 - Grouping by Tocher's method, based on Mahalanobis generalized distance of 12 soybean cultivars, based on the characteristics evaluated at Formoso do Araguaia, TO, Brazil, off-season, 2007.

\begin{tabular}{ll}
\hline Group & \multicolumn{2}{c}{ Cultivars } \\
\hline \multirow{3}{*}{ I } & 'FT-104'; 'FT-106'; 'FT-107'; 'MSOY108'; \\
& 'MSOY109'; 'EMGOPA 314'; 'FT-2000'; \\
& 'CONQUISTA'; 'CRISTALINA'; 'FT- \\
II & ESTRELA' 'DM-NOBRE' \\
\hline
\end{tabular}

the starting point for a more thorough assessment of them, in order to realize its use in breeding programs.

The relative contribution of each characteristic on genetic dissimilarity, according to method of SINGH (1981) showed that two of these characters contributed with $56.9 \%$ of genetic divergence, while others contributed only $43.0 \%$ (Table 4 ). The number of days to maturation and plant height were more efficient in explaining the dissimilarity among cultivars and should be prioritized in choice of parents in breeding programs.

The weight of 100 seeds although had low amplitude (Table 2) was third in importance in the study of divergence (11.93\%). Grain yield, in turn, contributed little in divergence, with about $6.61 \%$, although it has also shown great amplitude (750.9 to $1239.3 \mathrm{~kg} \mathrm{ha}^{-1}$ ). However, this trait is important in the breeding process, since the selection of parents with higher productivity in crosses will result in a greater probability of obtaining elite lines.

The grouping criterion adopted by the hierarchical method of nearest neighbor established that first a group of similar cultivars must be formed, and the distances of the others are calculated relative to the formed groups (CRUZ \& REGAZZI, 2004). The separation into groups in these types of graphics is done in a 
Table 4 - Relative contribution (\%) of the characteristics to the variability of soybean cultivars, by the method proposed by Singh (1981), at Formoso do Araguaia, TO, Brazil, off-season, 2007.

\begin{tabular}{lc}
\hline Characteristics & $\begin{array}{c}\text { Relative contribution } \\
\text { (\%) }\end{array}$ \\
\hline Number of days to maturity (days) & 40.94 \\
Plant height (cm) & 16.03 \\
Weight of 100 Seeds (g) & 11.93 \\
Number of pods per plant & 9.14 \\
Number of days to flowering (days) & 8.96 \\
Grain yield (kg ha ${ }^{-1}$ ) & 6.61 \\
Height of first pod insertion (cm) & 4.88 \\
Number of seeds per pod & 2.39 \\
\hline
\end{tabular}

subjective way by choosing a cutoff point in the distance scale (FUZATTO et al., 2002), which was carried out in $60 \%$ of the distance. By this technique, the combination of cultivars 'FT-2000' and 'CONQUISTA' showed the shortest distance and the larger distance was attributed to 'EMGOPA-314' and 'DOKO' combination, considered as $100 \%$ of distance for establishing the dendrogram.

It was observed the formation of two distinct groups (Figure 1), which were identical to those groups formed by Tocher's method. The cultivar 'DOKO', showed the highest number of days for maturation, plants height and weight of 100 seeds, which were the most important trait for the cultivar discrimination, was assigned only to this group.

The analysis of averages comparison, with the established groupings by Tocher and nearest neighbor method, allows the identification of those which will be the promising crossings as well as those that may result in restricted variability in segregating generations, such as those carried out between parents from the same group.

It can be expected as promising the following hybridizations: 'DOKO’ $x$ ‘CONQUISTA' and 'DOKO’ $x$ 'FT-2000', since the cultivars were dissimilar and showed high grain yield and acceptable characteristics regarding plant height and first pod insertion, suggesting that, when used in artificial hybridizations in breeding program, will enable to increase the number of desirables recombinants, so that could be used as sources of superior genetic constitutions.

\section{CONCLUSION}

The presence of genetic divergence allowed the identification of dissimilar cultivars and with high average in the studied characteristics. The optimization of Tocher and nearest neighbor method agreed between themselves. The characteristics number of days to maturity, plant height and weight of 100 seeds were those that most contributed to genetic dissimilarity. The hybridizations ‘DOKO’ x ‘CONQUISTA' and ‘DOKO’ $x$ 'FT-2000’ are promising to obtain superior genotypes.

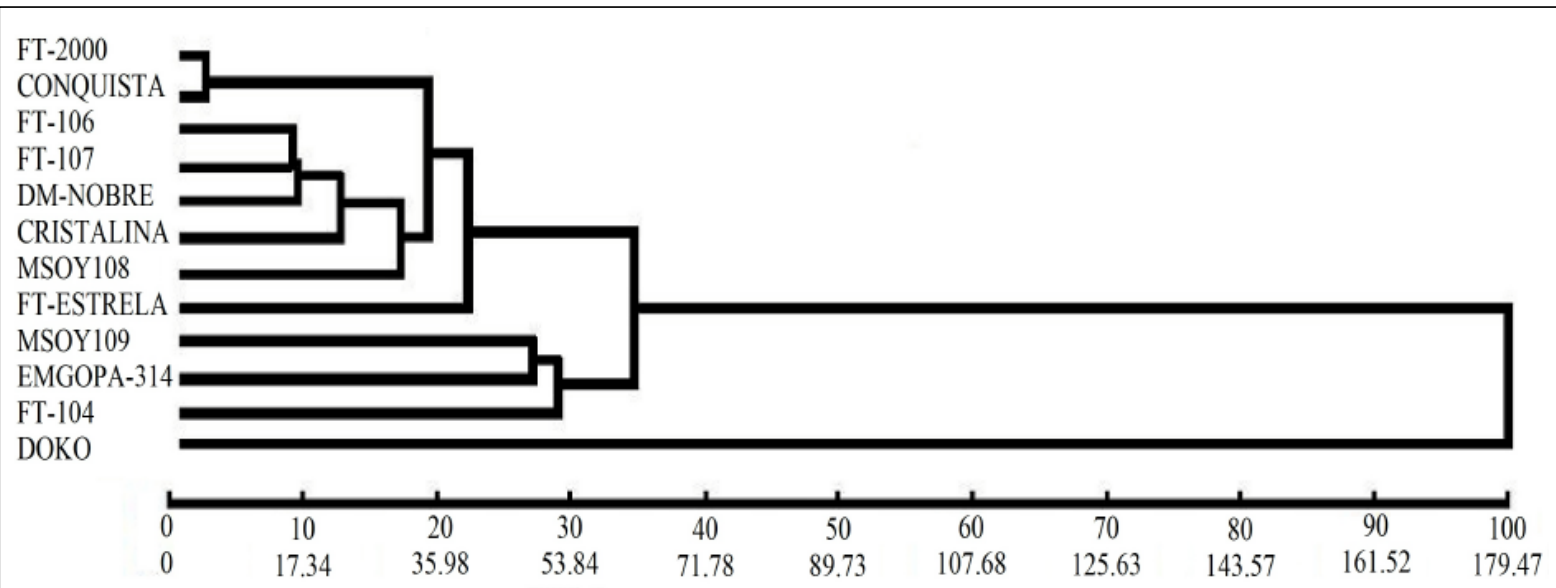

Figure 1 - Dendrogram of genetic dissimilarity, obtained by the technique of nearest neighbor, using the Mahalanobis generalized distance as the dissimilarity measure among soybean cultivars at Formoso do Araguaia, TO, Brazil, off-season, 2007.

Ciência Rural, v.42, n.3, mar, 2012. 


\section{REFERENCES}

ABREU, A.F.B. et al. Selection potential for seed yield from intra and inter-racial populations in common bean. Euphytica, v.108, n.2, p.121-127, 1999. Available from: <http:// www.springerlink.com/content/ r41xl662302wxr34/>. Accessed: Feb. 17, 2011. doi: 10.1023/A:1003608310384.

ALMEIDA, R.D. et al. Divergência genética entre cultivares de soja, sob condições de várzea irrigada, no Sul do Estado Tocantins. Revista Ciência Agronômica, v.42, n.1, p.108-115, 2011. Available from: <www.scielo.br/scielo.php?script=sci_arttext\&pid=S180666902011000100014\&lng=en\&nrm=iso>. Accessed: Ago. 02, 2011. doi: 10.1590/S1806-66902011000100014.

ARAVIND, G. Genetic variability and diversity studies in soybean [Glycine max (l.) Merrill]. 2006. 103f. Dissertation (Master in Genetics and Plant Breeding) - University of Agricultural Sciences, Dharwad, Índia.

ASMUS, GL. Reação de genótipos de soja ao nematóide reniforme. Tropical Plant Pathology, v.33, n.1, p.69-71, 2008. Available from: <http://www.scielo.br/scielo.php?script=sci_arttext\&pid=S1982$56762008000100012 \& \operatorname{lng}=$ =n\&nrm=iso>. Accessed: Feb. 20, 2011. doi: 10.1590/S1982-56762008000100012.

BARROS, H.B. et al. Efeito das épocas de semeadura no comportamento de cultivares de soja, no sul do estado do Tocantins. Ceres, v.50, n.291, p.565-572, 2003. Available from: <www.ceres.ufv.br/ceres/revistas/V50N291P23603.pdf>. Accessed: Feb. 20, 2011.

BOARD, J.E. et al. Path analysis identify indirect selection criteria for yield of late planted soybean. Crop Science, v.37, n.3, p.879-884, 1997. Available from: <www.crops.org/ publications/cs/abstracts/37/3/CS0370030879>. Acessed: Jan. 15, 2011. doi: 10.2135/cropsci1997.0011183X003700030030x.

CARPENTIERI-PÍPOLO, V. et al. Seleção de genótipos parentais de acerola com base na divergência genética multivariada. Pesquisa Agropecuária Brasileira, v.35, n.8, p.1613-1619, 2000. Available from: <www.scielo.br/scielo.php?script=sci_arttext\&pid=S0100204X2000000800014\&lng=en\&nrm=iso>. Accessed: Jan. 20, 2011. doi: 10.1590/S0100-204X2000000800014.

CEOLIN, A.C.G. et al. Genetic divergence of the common bean (Phaseolus vulgaris L.) group carioca using morpho-agronomic traits by multivariate analyses. Hereditas, v.144, n.1, p.1-9, 2007. Available from: <http://onlinelibrary.wiley.com/doi/ 10.1111/j.2006.0018-0661.01943.x/abstract>. Accessed: Jan. 21, 2011. doi: 10.1111/j.2006.0018-0661.01943.x.

CRUZ, C.D.; REGAZZI, A.J. Modelos biométricos aplicados ao melhoramento genético. Viçosa: UFV, 2004. 480p.
FUZATTO, S.R. et al. Divergência genética e sua relação com os cruzamentos dialélicos na cultura do milho. Ciência e Agrotecnologia, v.26, n.1, p.22-32, 2002. Available from: <www.editora.ufla.br/site/_adm/upload/revista/26-12002_03.pdf>. Accessed: Jan. 21, 2011.

IQBAL, Z. et al. Genetic divergence and correlation studies of soybean [Glycine max (l.) Merrill.] genotypes. Pakistan Journal of Botanic, v.42, n.2, p.971-976, 2010. Available from: <www.pakbs.org/pjbot/PDFs/42(2)/PJB42(2)0971.pdf>. Accessed: Ago. 20, 2011.

LIU, M. et al. Genetic diversity of Shaanxi soybean landraces based on agronomic traits and SSR markers. African Journal of Biotechnology, v.10, n.24, p.4823-4837, 2011. Available from: <www.academicjournals.org/AJB/pdf2011/6Jun/ Liu20et\%20al.pdf>. Accessed: Ago. 02, 2011.

MAIA, M.C.C et al. Adaptabilidade e estabilidade de linhagens experimentais de soja selecionadas para caracteres agronômicos através de método uni-multivariado. Bragantia, v.65, n.2, p.215226, 2006. Available from: <www.scielo.br/pdf/\%0D/brag/v65n2/ 30483.pdf>. Accessed: Ago. 02, 2011. doi: 10.1590/S000687052006000200004 .

MALIK, M.F.A et al. Investigation and comparison of some morphological traits of the soybean populations using cluster analysis. Pakistan Journal of Botanic, v.43, n.2, p.12491255, 2011. Available from: <www.pakbs.org/pjbot/PDF/43(2)/ PJB43(2)1249.pdf>. Accessed: Ago. 02, 2011.

MIKEL, M.A. et al. Genetic diversity and agronomic improvement of north american soybean germplasm. Crop Science, v.50, n.4, p.1219-1229, 2010. Available from: <www.crops.org/publications/cs/abstracts/50/4/1219>. Accessed: Ago. 02, 2011. doi: 10.2135/cropsci2009.08.0456.

PATIL, S.S. et al. Genetic diversity in soybean. Legume Research, v.34, n.1, p.68-70, 2011. Available from: <www.arccjournals.com/legume-research/march-2011.html>. Accessed: Ago. 02, 2011.

RAO, C.R. Advanced statistical methods in biometric research. New York: John Willey, 1952. 390p.

SEDIYAMA, T. et al. Melhoramento da soja. In: BORÉM, A. Melhoramento de espécies cultivadas. Viçosa: UFV, 2005. 969p.

SINGH, D. The relative importance of characters affecting genetic divergence. Indian Journal of Genetic and Plant Breeding. v.41, n.2, p.237-245, 1981. 